\title{
Evaluation of Alpha-Thalassemia Mutations in Cases with Hypochromic Microcytic Anemia: The İstanbul Perspective
}

\author{
Hipokromik Mikrositer Anemili Olgularda Alfa Talasemi \\ Mutasyonlarının Değerlendirmesi: İstanbul Perspektifi
}

Zeynep Karakaş1, Begüm Koç¹, Sonay Temurhan², Tuğba Elgünn², Serap Karaman'1, Gamze Asker ${ }^{3}$, Genco Gençay ${ }^{3}$, Çetin Timur ${ }^{4}$, Zeynep Yıldız Yıldırmak' ${ }^{5}$ Tiraje Celkan 6 , Ömer Devecioğlu1, Filiz Aydın²

1İstanbul University İstanbul Faculty of Medicine, Department of Pediatric Hematology-Oncology, İstanbul, Turkey

2̇́stanbul University İstanbul Faculty of Medicine, Department of Medical Biology, İstanbul, Turkey

3̇ंstanbul University İstanbul Faculty of Medicine, Department of Pediatrics, İstanbul, Turkey

${ }^{4}$ Göztepe Education and Research Hospital, Clinic of Pediatric Hematology, İstanbul, Turkey

5 Şişli Etfal Education and Research Hospital, Clinic of Pediatric Hematology, İstanbul, Turkey

6İstanbul University Cerrahpaşa Faculty of Medicine, Department of Pediatric Hematology-Oncology, İstanbul, Turkey

\begin{abstract}
:
Objective: Alpha thalassemia syndromes are caused by mutations on one or more of the four $\alpha$-globin genes. Mutations could be either more commonly deletional or non-deletional. As some deletions (3.7 and 4.2) cause $\alpha^{+}$-thalassemia, some cause (-20.5, MED, THAI, FIL) $\alpha^{0}$-thalassemia. The aim of this study was to determine alpha thalassemia mutations in patients with unsolved hypochromic microcytic anemia and to evaluate types of mutations.

Material and Methods: Two hundred six patients with hypochromic microcytic anemia were evaluated for alpha thalassemia. A venous blood sample of $2 \mathrm{~mL}$ was drawn from each patient for DNA isolation. The samples were investigated for $\alpha$-thalassemia mutations by using the Vienna Lab $\alpha$-Globlin StripAssay TM commercial kit.

Results: Fourteen different mutations were determined in 95 (46.1\%) patients. The most common mutation was the 3.7 single gene deletion and was found in 37 patients ( $\mathrm{n}=37 / 95,39 \%)$. Others common mutations were the $20.5 \mathrm{~kb}$ double gene deletion ( $\mathrm{n}=20$ patients, $21 \%$ ), MED double gene deletion ( $\mathrm{n}=17$ patients, $17.9 \%), \alpha 2$ IVS1 ( $\mathrm{n}=10$ patients, $10.5 \%$ ), $\alpha 2$ cd142 Hb Koya Dora ( $\mathrm{n}=6$ patients, 6.3\%), $\alpha 2$ polyAl (Saudi type) ( $\mathrm{n}=6$ patients, $6.3 \%$ ), 4.2 single gene deletion ( $\mathrm{n}=4$ patients, $4.2 \%$ ), $\alpha 1$ cd14 ( $\mathrm{n}=2$ patients, $2.1 \%$ ), and -FIL mutation ( $\mathrm{n}=2$ patients $2.1 \%$ ), respectively. Hb Adana, Hb Icaria, $\alpha 2$ init cd and $\alpha 2$ polyA2 (Turkish type) were found in $1 \%$ of the patients $(n=1)$. Seven patients $(7.4 \%)$ had $\alpha$-thalassemia triplication. In our study, three mutations (Hb Icaria, $\alpha 1 \mathrm{~cd} 14, \alpha 2$ init.cd) were determined firstly in Turkey. Seven mutations (-SEA, -THAI, Hb Constant Spring, $\alpha 2$ cd19, $\alpha 2$ cd59, $\alpha 2$ cd125, Hb Paksé) were not determined in this study.

Conclusion: Alpha thalassemia should be considered in the differential diagnosis of hypochromic microcytic anemia especially in cases without iron deficiency and $\beta$-thalassemia carrier state. Genetic testing should be performed for the suspicious cases. We also recommend that a national database with all mutations in Turkey should be created to screen the alpha thalassemia cost-effectively.
\end{abstract}

Keywords: Anemia, Alpha thalassemia, Hb Adana, Hb Icaria, Hb Koya Dora, Mutation, Thalassemia

Address for Correspondence: Begüm KOÇ, M.D.,

İstanbul University İstanbul Faculty of Medicine, Department of Pediatric Hematology-Oncology, İstanbul, Turkey

Phone: +90 5059062791 E-mail: begumsirins@hotmail.com

Received/Geliş tarihi : May 25, 2014

Accepted/Kabul tarihi : October 13, 2014 


\section{Öz:}

Amaç: Alfa talasemi sendromları, bir ya da daha fazla $\alpha$-globin genindeki mutasyonlardan kaynaklanır. Mutasyonlar genelikle delesyonel olmakla birlikte non-delesyonel de olabilir. Bazı delesyonlar (3.7 ve 4.2) $\alpha^{+}$-talasemiye neden olurken bazıları da (-20.5, MED, THAI, FIL) $\alpha^{0}$-talasemiye yol açar. Bu çalışma ile İstanbul ilinde, diğer nedenlerle açıklanamayan hipokrom mikrositer anemili olgularda alfa talasemi mutasyonlarını belirlemeyi ve mutasyon tiplerini değerlendirmeyi amaçladık.

Gereç ve Yöntemler: Bu çalışmada 206 hasta alfa talasemi için değerlendirmeye alındı. Her hastadan DNA izolasyonu için $2 \mathrm{ml}$ venöz kan örneği alındı. Strip analiz kiti (ViennaLab Diagnostics GmbH, Austria) kullanılarak alfa talasemi mutasyonları araştırıldı.

Bulgular: Doksan beş hastada (\%46,1) 14 farklı mutasyon tespit edildi. En sık saptanan mutasyon 3.7 tek gen delesyonu idi ( $n=37$ hasta, \%39). Diğer mutasyonlar sıklık sırasına göre; 20,5 kb çift gen delesyonu ( $n=20, \% 21)$, MED çift gen delesyonu ( $n=17$, $\% 17,9), \alpha 2$ IVS1 (n=10, \%10,5), $\alpha 2$ poly-A1 (Suudi tip) ( $n=6, \% 6,3)$, Hb Koya Dora $(n=6, \% 6,3), 4.2$ tek gen delesyonu ( $n=4$, $\% 4,2)$, FIL mutasyonu (n=2, \%2,1) ve $\alpha 1$ cd $14(\mathrm{n}=2, \% 2,1)$ idi. Hb Adana (n=1), Hb Ikaria (n=1), $\alpha 2$ init cd (n=1) ve $\alpha 2$ poly-A2 (Türk tipi) (n=1) hastaların \%1'inde saptandı. Yedi hasta alfa talasemi gen triplikasyonu $(\% 7,4)$ taşıyordu. Çalışmamızda üç mutasyon (Hb Icaria, $\alpha 1$ cd14, $\alpha 2$ init.cd) Türkiye'de ilk kez tespit edildi. Yedi mutasyon ise (-SEA, -THAI, Hb Constant Spring, $\alpha 2$ cd19, $\alpha 2$ cd59, $\alpha 2$ cd125, Hb Paksé) hastalarımızda hiç saptanmadı.

Sonuç: Alfa talasemi, hipokrom mikrositer anemilerin ayırıcı tanısında özellikle de demir eksikliği ve beta-talasemi taşıyıcılığının saptanmadığı durumlarda akla getirilmelidir. Şüpheli olgularda genetik açıdan mutasyon taraması yapılmalıdır. Alfa talasemi taramasını daha uygun maliyetle yapabilmek için Türkiye'de saptanan tüm alfa talasemi mutasyonlarının toplandığı ulusal bir veritabanı oluşturulmasını önermekteyiz.

Anahtar Sözcükler: Alfa talasemi, Anemi, Hb Adana, Hb Icaria, Hb Koya Dora, Mutasyon, Talasemi

\section{Introduction}

Alpha thalassemia syndromes are inherited autosomal recessively and caused by defects on one or more of the $4 \alpha$-globin genes $(\alpha \alpha / \alpha \alpha)$, leading to reduced or absent production of the alpha-globin polypeptide chains $[1,2]$. The $\alpha$-globin gene mutations could be either the more common deletion (partial $\left(\alpha^{+}\right)$deletions or total $\left(\alpha^{0}\right)$ deletions) or non-deletional types. There are reported to be more than 40 deletion mutations in various studies $[2,3,4]$. The most common alpha-thalassemia mutations in the world are the 3.7 single-gene deletions. While $\alpha^{+-}$thalassemia is caused by single-gene deletions (such as 3.7 and 4.2), $\alpha^{0}$-thalassemia is caused by double-gene deletions (such as -20.5, SEA, MED, THAI, and FIL). Three-gene deletions ( $\alpha^{+}$with $\alpha^{0}$ thalassemia) or a combination of two-gene deletions with a non-deletion mutation cause $\mathrm{HbH}$ disease. If there are deletion mutations on $4 \alpha$-genes, Hb Bart's hydrops fetalis develops $[5,6]$. These large deletions have particularly severe phenotypes. On the other hand, non-deletion mutations result in structurally abnormal and instable hemoglobin variants such as Hb Constant Spring, which is the most common, and Hb $\alpha^{\text {TSaudi }} \alpha$, polyA $\alpha 2$, Hb Koya Dora, and Hb Quong Sze $[4,7]$. Non-deletion mutations may reduce $\alpha$-globin chain synthesis more severely than most of the deletion mutations [1]. More than 70 non-deletion mutations have been reported [8].
The clinical course of alpha thalassemia is correlated with the number of affected $\alpha$-globin genes. There are 4 clinical definitions of $\alpha$-thalassemia syndromes: 1) silent carrier, defined as heterozygous $\alpha^{+}$-thalassemia $(-\alpha / \alpha \alpha)$ with mostly normal hemoglobin or mild hypochromic anemia; 2) $\alpha$-thalassemia trait, defined as heterozygous $\alpha^{0}$ thalassemia $(--/ \alpha \alpha)$ or homozygous $\alpha^{+}$-thalassemia $(-\alpha /-\alpha)$ with mild anemia; 3$) \mathrm{HbH}$ disease, defined as compound heterozygous $\alpha^{+} / \alpha^{0}$-thalassemia with 3 inactive $\alpha$-genes (--/$\alpha$ ) with moderate hemolytic anemia; and 4) Hb Bart's, defined as homozygous $\alpha^{0}$-thalassemia (----) with hydrops fetalis. Silent carriers and those with $\alpha$-thalassemia trait are generally clinically asymptomatic and do not need any treatment. Patients with $\mathrm{HbH}$ disease usually have moderate anemia with hepatosplenomegaly; some of them need periodic blood transfusion and folic acid supplementation. Hb Bart's causes hydrops fetalis prenatally and is fatal if not treated with intrauterine blood transfusions $[2,3,8]$.

The aim of this study was to determine alpha-thalassemia mutations in patients with unsolved hypochromic microcytic anemia and to evaluate the types of mutations.

\section{Materials and Methods}

Two hundred six individuals either having hypochromic microcytic anemia or being parents and/or siblings of a patient with $\mathrm{HbH}$ disease were referred to our institution for screening 
of alpha thalassemia mutations in İstanbul. A venous blood sample of $2 \mathrm{~mL}$ was drawn from each patient into the EDTA tubes for DNA isolation. In vitro amplification was made with polymerase chain reaction (PCR) multiplex method using Biotin marked primers belonging to alpha globin encoding gene zones. Products of the amplification process were investigated for mutations of the alpha globulin genes using the Vienna Lab $\alpha$-Globlin Strip Assay TM commercial kit including 21 alpha thalassemia mutations. These mutations are shown in Table 1.

\section{Results}

Ninety-five patients (46.1\%) with alpha thalassemia mutations were identified. The patients were aged from 1 to 46 years; 52 of those were male and 43 were female. Deletion mutations were detected in $69.3 \%$ of the patients whereas non-deletion mutations in $30.6 \%$. The most common mutation was the 3.7 single gene deletion and was found in 37 patients (39\%). Others common mutations were the 20.5 $\mathrm{kb}$ double gene deletion ( $\mathrm{n}=20$ patients, 21\%), MED double gene deletion ( $\mathrm{n}=17$ patients, $17.9 \%), \alpha 2$ IVS1 ( $\mathrm{n}=10$ patients, $10.5 \%), \alpha 2$ cd142 Hb Koya Dora ( $\mathrm{n}=6$ patients, 6.3\%), $\alpha 2$ polyAl (Saudi type) ( $\mathrm{n}=6$ patients, 6.3\%), 4.2 single gene deletion ( $\mathrm{n}=4$ patients, $4.2 \%$ ), $\alpha \mathrm{l} \mathrm{cdl} 4$ ( $\mathrm{n}=2$ patients, $2.1 \%$ ), and -FIL mutation ( $\mathrm{n}=2$ patients $2.1 \%$ ), respectively. Hb Adana, $\mathrm{Hb}$ Icaria, $\alpha 2$ init $\mathrm{cd}$ and $\alpha 2$ polyA2 (Turkish type) were found in $1 \%$ of the patients $(n=1)$. Seven patients $(7.4 \%)$ had $\alpha$-thalassemia triplication (Table 2). Some deletions (-SEA, -THAI) and some mutations ( $\alpha 2 \operatorname{cd} 19, \alpha 2 \operatorname{cd} 59, \alpha 2 \operatorname{cd} 125$, $\mathrm{Hb}$ Paksé and $\mathrm{Hb}$ Constant Spring) were not determined in this study (Table 1).

Fourteen distinct alpha thalassemia mutations were detected in 95 patients. In the total of 190 alleles, the most common mutation was the 3.7 single gene deletion $(n=37$ alleles, 19.5\%). The allele frequencies of the other mutations were: $20.5 \mathrm{~kb}$ double gene deletion ( $\mathrm{n}=20$ alleles, $10.5 \%)$, MED double gene deletion ( $\mathrm{n}=17$ alleles, 8.9\%), $\alpha 2$ IVS1 ( $\mathrm{n}=10$ alleles, 5.2\%), $\alpha 2$ polyA1 (Saudi type) ( $\mathrm{n}=7$ alleles, 3.7\%), alpha triplication $(\mathrm{n}=7$ alleles, $3.7 \%)$, Hb Koya Dora $(\mathrm{n}=6$ alleles, $3.1 \%$ ), 4.2 single gene deletion( $\mathrm{n}=4$ alleles, $2.1 \%$ ), $\alpha 1$ cd14 ( $\mathrm{n}=2$ alleles, $1 \%$ ), and -FIL mutation ( $\mathrm{n}=2$ alleles, $1 \%)$, respectively (Table 3 ). The allele frequencies of Hb Adana, $\mathrm{Hb}$ Icaria, $\alpha 2$ init cd and $\alpha 2$ polyA2 (Turkish type) were found to be $0.5 \%$ (Table 3). Three mutations (Hb Icaria, $\alpha 1$ cdl4, $\alpha 2$ init.cd) were detected for the first time in Turkey.

The genetic results of the patients showed that 28 patients (29.4\%) were silent carriers, 45 patients $(47.3 \%)$ had alpha thalassemia trait, and 15 patients ( $15.8 \%$ ) had Hemoglobin $\mathrm{H}$ disease (Table 2). Seven patients with alpha triplication were not grouped phenotypically.

\section{Discussion}

According to reports from the World Health Organization, at least $20 \%$ of the world's population is alpha-thalassemia carrier [9]. The geographic distribution of $\alpha$-thalassemia mutations is especially concentrated in the Mediterranean and Middle Eastern regions, where up to $40 \%$ of people are carriers $[4,10]$. Turkey also has a high alpha-thalassemia frequency because of its geographic position.

Table 1. Positions of the 21 alpha-gene mutations in the strip assay kit.

\begin{tabular}{|c|c|c|}
\hline No & Position & Gene Mutation/Deletion \\
\hline 1 & $-\alpha^{3.7}$ & Single-gene deletion \\
\hline 2 & $-\alpha^{4.2}$ & Single-gene deletion \\
\hline 3 & $(\alpha)^{20.5}$ & Double-gene deletion \\
\hline 4 & --MED & Double-gene deletion \\
\hline 5 & $\alpha 2$ IVS1 & 5-bp deletion \\
\hline 6 & $\alpha \alpha \alpha$ anti-3.7 & Gene triplication \\
\hline 7 & $\alpha 2$ cd 142 & A $>C$ (Hb Koya Dora $)$ \\
\hline 8 & $\alpha 2$ polyA-1 & AATAAA $>$ AATAAG (Saudi type) \\
\hline 9 & --FIL & Double-gene deletion \\
\hline 10 & $\alpha 1 \mathrm{~cd} 14$ & $\mathrm{G}>\mathrm{A}$ \\
\hline 11 & $\alpha 1$ cd 59 & G>A (Hb Adana) \\
\hline 12 & $\alpha 2$ polyA-2 & $\begin{array}{l}\text { AATAAA >AATGAA (Turkish } \\
\text { type) }\end{array}$ \\
\hline 13 & $\alpha 2$ cd 142 & $\mathrm{~T}>\mathrm{A}(\mathrm{Hb}$ Icaria $)$ \\
\hline 14 & $\alpha 2$ init.cd & ATG $>$ ACG \\
\hline $15^{*}$ & --THAI & Double-gene deletion \\
\hline $16^{*}$ & --SEA & Double-gene deletion \\
\hline $17^{*}$ & $\alpha 2 \operatorname{cd} 125$ & T>C (Hb Quong Sze) \\
\hline $18^{*}$ & $\alpha 2$ cd 142 & $\mathrm{~T}>\mathrm{C}$ (Hb Constant Spring) \\
\hline $19 *$ & $\alpha 2$ cd 19 & $-G$ \\
\hline 20 * & $\alpha 2$ cd 142 & A > T(Hb Paksé) \\
\hline $21^{*}$ & $\alpha 2 \operatorname{cd} 59$ & $G>A$ \\
\hline
\end{tabular}


The first publication on alpha-thalassemia from Turkey was that of Özsoylu and Malik, who studied alpha-thalassemia by column chromatography in 1982 [11]. The first screening study of alpha-thalassemia by sensitive DNA method (gene mapping) was published in 1989 [12]. The frequency of alpha-thalassemia was detected at $3.6 \%$, while the frequency of alpha-gene triplication was also 3.6\%. Arcasoy reported that the frequency of alpha-thalassemia in Turkey was $0.25 \%$ [13]. Kılınç et al. studied the cord blood of newborns and reported the frequency of alpha-thalassemia carriers to

Table 2. Genotypes and phenotypes of the patients with alpha-thalassemia.

\begin{tabular}{|c|c|c|c|}
\hline Genotype & Mutation Type & Phenotype & n (\%) \\
\hline$\alpha^{-3.7} \alpha / \alpha \alpha$ & Deletional & Silent carrier & 19 \\
\hline$(\alpha \alpha)^{-\mathrm{MED} / \alpha \alpha}$ & Deletional & $\alpha$-thal trait & 14 \\
\hline$\alpha-3.7 \alpha / \alpha^{-3.7} \alpha$ & Deletional & $\alpha$-thal trait & 7 \\
\hline$(\alpha \alpha)-20.5 / \alpha \alpha$ & Deletional & $\alpha$-thal trait & 13 \\
\hline$(\alpha \alpha)-20.5 / \alpha-3.7 \alpha$ & Deletional & $\mathrm{HbH}$ & 5 \\
\hline$(\alpha \alpha)-M E D / \alpha-4.2 \alpha$ & Deletional & $\mathrm{HbH}$ & 2 \\
\hline$\alpha-4.2 \alpha / \alpha$ & Deletional & Silent carrier & 1 \\
\hline \multirow[t]{2}{*}{$(\alpha \alpha)$ FIL $/ \alpha-3.7 \alpha$} & Deletional & $\mathrm{HbH}$ & 2 \\
\hline & Total & & $63(66.3 \%)$ \\
\hline$\alpha^{\mathrm{IVS1}} \alpha / \alpha \alpha$ & Non-deletional & Silent carrier & 3 \\
\hline$\alpha^{\mathrm{HbKD}^{*}} \alpha / \alpha \alpha$ & Non-deletional & Silent carrier & 4 \\
\hline$\alpha^{H b I C * *} \alpha / \alpha \alpha$ & Non-deletional & Silent carrier & 1 \\
\hline$\alpha^{\mathrm{PAl}} \alpha / \alpha \alpha$ & Non-deletional & $\alpha$-thal trait & 4 \\
\hline$\alpha^{\mathrm{IVSl}} \alpha / \alpha^{\mathrm{IVSl}} \alpha$ & Non-deletional & $\alpha$-thal trait & 2 \\
\hline$\alpha^{\mathrm{PAl}} \alpha / \alpha \mathrm{PAl}_{\alpha}$ & Non-deletional & $\mathrm{HbH}$ & 1 \\
\hline$\alpha \alpha^{\operatorname{cd} 14 / \alpha \alpha}$ & Non-deletional & $\alpha$-thal trait & 1 \\
\hline$\alpha \alpha^{\operatorname{cd} 14 / \alpha{ }^{H b K D} * \alpha}$ & Non-deletional & $\mathrm{HbH}$ & 1 \\
\hline \multirow[t]{2}{*}{$\alpha^{\text {init.cd }{ }^{* * *}} \alpha / \alpha^{\mathrm{PAl}} \alpha$} & Non-deletional & $\alpha$-thal trait & 1 \\
\hline & Total & & $18(19 \%)$ \\
\hline$\alpha^{-3.7} \alpha / \alpha^{I^{V S l}} \alpha$ & Deletional/non-deletional & $\alpha$-thal trait & 2 \\
\hline$(\alpha \alpha)^{-20.5 / \alpha{ }^{I V S 1} \alpha}$ & Deletional/non-deletional & $\mathrm{HbH}$ & 2 \\
\hline$(\alpha \alpha)-\mathrm{MED} / \alpha^{\mathrm{PA} 2} \alpha$ & Deletional/non-deletional & $\mathrm{HbH}$ & 1 \\
\hline$\alpha^{-4.2} \alpha / \alpha^{\mathrm{IVS1}} \alpha$ & Non-deletional & $\alpha$-thal trait & 1 \\
\hline \multirow[t]{2}{*}{$\alpha^{-3.7} \alpha / \alpha \alpha^{\operatorname{cd} 59}$} & Deletional/non-deletional & $\mathrm{HbH}$ & 1 \\
\hline & Total & & $7(7.3 \%)$ \\
\hline$\alpha^{\text {anti-3.7 }} \alpha / \alpha \alpha$ & Triplication & & 5 \\
\hline$\alpha^{\text {anti-3.7 }} \alpha / \alpha^{H b K D *} \alpha$ & Triplication/non-deletional & & 1 \\
\hline \multirow[t]{2}{*}{$\alpha^{\text {anti-3.7 }} \alpha / \alpha^{-3.7} \alpha$} & Triplication/deletional & & 1 \\
\hline & Total & & $7(7.3 \%)$ \\
\hline Total & & & $95(100 \%)$ \\
\hline
\end{tabular}

*HbKD: Hb Koya Dora, **HbIC: Hb Icaria, n: patient number. 
Table 3. The allele frequencies of the alpha thalassemia mutations in different studies from Turkey.

\begin{tabular}{|c|c|c|c|c|c|c|c|c|}
\hline $\begin{array}{l}\text { Alpha } \\
\text { Thalassemia } \\
\text { Mutations }\end{array}$ & $\begin{array}{l}\text { İstanbul } \\
\text { present } \\
\text { study, } \\
2014, \\
\text { n=95, \% }\end{array}$ & $\begin{array}{l}\text { Aegean } \\
\text { Onay et al., } \\
2013, \\
n=229, \% \\
{[24]}\end{array}$ & $\begin{array}{l}\text { Hatay } \\
\text { Celik et } \\
\text { al., 2013, } \\
\mathrm{n}=97, \% \\
{[19]}\end{array}$ & $\begin{array}{l}\text { Isparta } \\
\text { Sütçü et } \\
\text { al., 2011, } \\
\text { n=9,\% } \\
{[18]}\end{array}$ & $\begin{array}{l}\text { Adana } \\
\text { Guvenc et } \\
\text { al., 2010, } \\
\text { n=225,\% } \\
{[17]}\end{array}$ & $\begin{array}{l}\text { Çukurova } \\
\text { Çürük, } \\
2007, \\
\text { n=32,\% } \\
{[20]}\end{array}$ & $\begin{array}{l}\text { Turkey } \\
\text { Oner et } \\
\text { al., 1997, } \\
\text { n=25,\% } \\
{[21]}\end{array}$ & $\begin{array}{l}\text { Cyprus } \\
\text { Baysal et } \\
\text { al., 1995, } \\
\text { n=78, \% } \\
{[25]}\end{array}$ \\
\hline $\begin{array}{l}\text { Study } \\
\text { population }\end{array}$ & $\begin{array}{l}\text { Patients } \\
\text { with HMA }\end{array}$ & $\begin{array}{l}\text { Patients } \\
\text { with HMA }\end{array}$ & $\begin{array}{l}\text { Patients } \\
\text { with } \\
\text { HMA }\end{array}$ & - & $\begin{array}{l}\text { Premarital } \\
\text { couples/ } \\
\text { Patients } \\
\text { with HMA }\end{array}$ & $\begin{array}{l}\text { Patients with } \\
\mathrm{HbH}\end{array}$ & $\begin{array}{l}\text { Patients } \\
\text { with } \mathrm{HbH}\end{array}$ & $\begin{array}{l}\text { Patients } \\
\text { with } \mathrm{HbH}\end{array}$ \\
\hline Material Method & Strip assay & Strip assay & $\begin{array}{l}\text { Strip } \\
\text { assay }\end{array}$ & $\begin{array}{l}\text { Strip } \\
\text { assay }\end{array}$ & Strip assay & $\begin{array}{l}\text { Gene } \\
\text { mapping by } \\
\text { Q probe }\end{array}$ & DNA & DNA \\
\hline$-\alpha^{3.7}$ & 23.1 & 52.2 & 43.8 & 5.5 & 40.6 & 29.6 & 28 & 30 \\
\hline$(\alpha)^{20.5}$ & 9.4 & 14.2 & 0.5 & 11.1 & 3.3 & 18.8 & 22 & 4 \\
\hline --MED & 8.9 & 11 & 5.6 & 27.7 & 9.5 & 14.1 & 20 & 40 \\
\hline $\begin{array}{l}\alpha 2 \text { IVS1 } \\
\left(\alpha 2^{-5 n t}\right)\end{array}$ & 6.3 & 4 & 6.7 & 5.5 & 0 & 4.7 & 8 & 10 \\
\hline$\alpha \alpha \alpha$ anti 3.7 & 3.7 & 3.2 & 1.5 & 0 & 1.1 & 0 & 0 & 0 \\
\hline $\begin{array}{l}\alpha 2 \text { cd142 } \\
\text { (Hb Koya Dora) }\end{array}$ & 3.1 & 1.8 & 0 & 0 & 0 & 0 & & \\
\hline$\alpha 2$ polyA-1 & 3.7 & 9 & 0.5 & 0 & 0.7 & 4.7 & 0 & 12 \\
\hline$-\alpha^{4.2}$ & 2.1 & & 0.5 & 0 & 0.6 & 1.6 & 12 & 12 \\
\hline$\alpha 1 \mathrm{~cd} 14$ & 1 & & 0 & 0 & 0 & 0 & & \\
\hline --FIL & 1 & 3.2 & 0.5 & 0 & 0 & 0 & 0 & 0 \\
\hline$\alpha 2$ polyA-2 & 0.5 & 1.4 & 2.5 & 0 & 2 & 7.8 & 10 & 4 \\
\hline $\begin{array}{l}\alpha 2 \text { cd } 142 \\
\text { (Hb Icaria) }\end{array}$ & 0.5 & & 0 & 0 & 0 & 0 & & \\
\hline$\alpha 2$ init.cd & 0.5 & & 0 & 0 & 0 & 0 & 0 & 0 \\
\hline $\begin{array}{l}\alpha 1 \text { cd } 59 \\
\text { (Hb Adana) }\end{array}$ & 0.5 & & 0 & 0 & 0 & 6.2 & & \\
\hline
\end{tabular}

n: Patients with alpha thalassemia mutations, *HMA: Hypochromic microcytic anemia.

be $2.9 \%$ in the Adana region in 1986, while Canatan et al. reported the frequency of alpha-thalassemia as 2.5\%-6.5\% in the Antalya region $[14,15,16]$. Guvenc et al. reported the incidence of $\alpha$-thalassemia as $7.5 \%$ in selected patients in the Adana region [17]. The diagnosis of alpha-thalassemia is also important in patients with unsolved hypochromic microcytic anemia. We found a rate of alpha-thalassemia as high as $46.1 \%$ among selected patients with hypochromic microcytic anemia in İstanbul.
The types of alpha-thalassemia mutations are variable depending on geographic region. Although 21 mutations were screened, we found 14 different alpha-thalassemia mutations in patients who lived in İstanbul. The most common mutations were the 3.7 single-gene deletion, 20.5 double-gene deletion, MED double-gene deletion, $\alpha 2$ IVS-1, 3.7 gene triplication, Hb Koya Dora, $\alpha 2$ polyA1, 4.2 single-gene deletion, $\alpha 1 \mathrm{~cd} 14$, and FIL mutation, respectively. These mutations were seen in $95 \%$ of our patients, similar to reports from other parts of Turkey (Table 3). 
According to the study by Guvenc et al., the rate of 3.7-kb deletion was extremely high (53.3\%) in selected patients from Adana [17]. They also performed the largest study in Turkey with 3000 premarital couples and anemic patients, excluding those with iron deficiency, and they detected alpha-thalassemia mutations in 225 patients. They demonstrated 11 different genotypes; the 3.7 single-gene deletion and MED double-gene deletion were the most prevalent genotypes in their study.

Sütçü et al. reported that the most common alphathalassemia mutations were the MED double-gene deletion, 20.5-kb double gene deletion, 3.7 single-gene deletion, and a2IVS 1-5 nt, respectively, in the Isparta area in the south of Turkey [18]. Although they tested few patients and detected mutations in only 9 patients, their most common mutations were similar to those of other studies in Turkey.

Celik et al. demonstrated 9 distinct mutations and the frequencies of the mutations in Hatay [19]. They tested 330 individuals and detected mutations in 97 patients. Their inclusion criteria for the study were similar to ours. They reported that 3.7 single-gene deletions were the most common mutation at $43.81 \%$. In addition, they reported FIL doublegene deletion for the first time in 2012 in Turkey. We also detected FIL mutation in 2 patients in İstanbul. In their study, deletion mutations were detected in $81.8 \%$ of the patients and non-deletion mutations in $18.2 \%$, whereas deletion mutations were found in $69.3 \%$ and non-deletion mutations in $30.6 \%$ in our study. These findings are similar to those of other studies addressing alpha-thalassemia in the world.

$\mathrm{HbH}$ is the most common condition that arises from the deletions of $3 \alpha$-globin genes (--/- $\alpha)$ and rarely by the combination of deletion and non-deletion mutations affecting the $\alpha$-globin genes. There are also published studies from Turkey about $\mathrm{HbH}$ disease $[20,21,22,23]$. Çürük reported mutations in 32 patients with $\mathrm{HbH}$ disease [20]. In that study, 20 patients with $\mathrm{HbH}$ had 3 alpha-gene deletions, while the remaining 12 cases were caused by the combination of alphagene deletion and point mutation. In our study, 15 patients were evaluated as having $\mathrm{HbH}$ disease; 9 of them had $3 \alpha$-globin gene deletions, 2 of them had non-deletion mutations, and the other cases were caused by the combination of deletion and non-deletion mutations, as shown in Table 2.

We found a very heterogeneous distribution of alphathalassemia mutations. This heterogeneity could be because İstanbul is the city in Turkey receiving the most migrants. We present the results of our study and other studies from Turkey in Table $3[17,18,19,20,21,24,25]$. In our study, we found 3 mutations that not been reported previously in Turkey. One-third of the mutations from the strip assay kit were not determined, similar to other studies from different parts of Turkey.

In our study, patients were identified as being silent carriers, having alpha-thalassemia traits, or having $\mathrm{HbH}$ disease on the basis of genetic mutations. For example, patients with single-gene deletion were defined as silent carriers. We determined clinical definitions for the patients according to their genetic mutations. Most silent carriers have normal hemoglobin levels in the general population. Our results showed that the silent carriers had mild hypochromic microcytic anemia because our study group included only patients with hypochromic microcytic anemia. Finally, silent carriers of alpha-thalassemia could be mostly normal or mildly anemic, as shown in the literature $[2,3,8]$.

Screening for the 7 most common mutations, present in $>95 \%$ of patients, is recommended in Canada [26]. The strip assay method for alpha-thalassemia genetic testing can be used effectively due to homogeneity of mutations in the public. It is also cost-effective for the most commonly seen mutations in patients with otherwise unexplained, longstanding, hypochromic microcytic anemia.

In conclusion, we found a high rate $(46.1 \%)$ of alphathalassemia mutations among patients with long-standing hypochromic microcytic anemia. Alpha-thalassemia should be considered in the differential diagnosis of hypochromic microcytic anemia, especially in cases without iron deficiency and $\alpha$-thalassemia carrier states. Genetic testing should be performed for these suspicious cases. Furthermore, we recommend that a national database including all mutations in Turkey should be created to screen alpha-thalassemia mutations cost-effectively.

\section{Conflict of Interest Statement}

The author of this paper have no conflicts of interest, including specific financial interests, relationships, and/or affiliations relevant to the subject matter or materials included.

Informed Consent: It was taken, Concept: Zeynep Karakaş, Begüm Koç, Design: Zeynep Karakaş, Begüm Koç, Data Collection or Processing: Zeynep Karakaş, Begüm Koç, Serap Karaman, Gamze Asker, Genco Gençay, Çetin Timur, Zeynep Yıldız Yıldırmak, Tiraje Celkan, Ömer Devecioğlu, Analysis or Interpretation: Filiz Aydın, Sonay Temurhan, Tuğba Elgün, Literature Search: Zeynep Karakaş, Begüm Koç, Writing: Zeynep Karakaş, Begüm Koç.

Conflict of Interest: The authors of this paper have no conflicts of interest, including specific financial interests, relationships, and/or affiliations relevant to the subject matter or materials included. 


\section{References}

1. Harteveld CL, Higgs DR. $\alpha$-Thalassaemia. Orphanet J Rare Dis 2010;5:13

2. Singer ST. Variable clinical phenotypes of alpha-thalassemia syndromes. Scientific World Journal 2009;9:615-625.

3. Kohne E. Hemoglobinopathies: clinical manifestations, diagnosis, and treatment. Dtsch Arztebl Int 2011;108:532540.

4. Vichinsky EP. Alpha thalassemia major--new mutations, intrauterine management, and outcomes. Hematology Am Soc Hematol Educ Program 2009:35-41.

5. Chui DH, Waye JS. Hydrops fetalis caused by alphathalassemia: an emerging health care problem. Blood 1998;91:2213-2222.

6. Vichinsky EP. Clinical manifestations of $\alpha$-thalassemia. Cold Spring Harb Perspect Med 2013;3:011742.

7. Galanello R, Cao A. Gene test review. Alpha-thalassemia. Genet Med 2011;13:83-88.

8. Rachmilewitz EA, Giardina PJ. How I treat thalassemia. Blood 2011;118:3479-3488.

9. Modell B, Darlison M. Global epidemiology of haemoglobin disorders and derived service indicators. Bull World Health Organ 2008;86:480-487.

10. Weatherall DJ, Clegg JB. Inherited haemoglobin disorders: an increasing global health problem. Bull World Health Organ 2001;79:704-712.

11. Özsoylu \$̧, Malik SA. Incidence of alpha thalassemia in Turkey. Turk J Pediatr 1982;24:235-244.

12. Fei YJ, Kutlar F, Harris HF, Wilson MM, Milana A, Sciacca P, Schiliro G, Masala B, Manca L, Altay C, Gurgey A, Huisman TJH. A search for anomalies in the zeta, alpha, beta, and gamma globin gene arrangements in normal black, Italian, Turkish, and Spanish newborns. Hemoglobin 1989;13:4565.

13. Arcasoy A. Türkiye'de Thalassemia Taşıyıcı Siklığı. Ankara, Turkey, Ankara Thalassemia Association, 1991 (in Turkish).

14. Klınç Y, Kumi M, Gürgey A, Altay C. Adana Bölgesi'nde doğan bebeklerde kordon kanı çalısması ile $\beta$-talassemi, glukoz6-fosfat dehidrogenaz enzim eksikligi ve $\mathrm{Hb}$ S sılkğının araştırılması. DOĞA 1986;10:162-167 (in Turkish).
15. Canatan D. Türkiye'de hemoglobinopatilerin epidemiyolojisi. HematoLog 2014;4-1:11-23 (in Turkish).

16. Canatan D, Oğuz N, Guvendik İ, Yıldırım S. The incidence of alpha-thalassemia in Antalya, Turkey. Turk J Haematol 2002;19:433-434.

17. Guvenc B, Yildiz SM, Tekinturhan F, Dincer S, Akyuzluer I, Okten S, Erkman H. Molecular characterization of alphathalassemia in Adana, Turkey: a single center study. Acta Haematol 2010;124:197-200.

18. Sütçü R, Aylak F, Koçak H, Sipahi T, Vural H, Delibaş N. The investigation of distribution of hereditary alpha-thalassemia mutations in Isparta reservoir. Eur J Basic Med Sci 2011;1:2832.

19. Celik MM, Gunesacar R, Oktay G, Duran GG, Kaya H. Spectrum of $\alpha$-thalassemia mutations including first observation of --FIL deletion in Hatay Province, Turkey. Blood Cells Mol Dis 2013;51:27-30.

20. Çürük MA. Hb H $(\alpha 4)$ disease in Çukurova, southern Turkey. Hemoglobin 2007;31:265-271.

21. Oner C, Gürgey A, Oner R, Balkan H, Gümrük F, Baysal $\mathrm{E}$, Altay $\mathrm{C}$. The molecular basis of $\mathrm{Hb} \mathrm{H}$ disease in Turkey. Hemoglobin 1997;21:41-51.

22. Yüreğir GT, Aksoy K, Çürük MA, Dikmen N, Fei YJ, Baysal E, Huisman $\mathrm{TH}$. Hb H disease in a Turkish family resulting from the interaction of a deletional alpha-thalassemia- 1 and newly discovered poly A mutation. Br J Haematol 2008;80:527-532.

23. Çürük MA, Kilinç Y, Evrüke C, Özgünen FT, Aksoy K, Yüreğir GT. Prenatal diagnosis of $\mathrm{Hb} \mathrm{H}$ disease caused by alpha homozygosity for the $\alpha 2$ poly A(AATAAA-AATAAG) mutation. Hemoglobin 2001;25:255-258.

24. Onay H, Aykut A, Karaca E, et al. Ege bölgesinde alfa talasemi mutasyonlarının dağılımının araştırılması. İçinde: 1. Hematolojik Genetik Sempozyumu Bildiri Özet Kitabı, İzmir, Türkiye, 2013, p. 95 (in Turkish).

25. Baysal E, Kleanthous M, Bozkurt G, Kyrri A, Kalogirou E, Angastiniotis M, Ioannou P, Huisman TH. Alpha-thalassaemia in the population of Cyprus. Br J Haematol 1995;89:496-499.

26. Waye JS, Eng B. Diagnostic testing for a-globin gene disorders in a heterogeneous North American population. Int J Lab Hematol 2013;35:306-313. 